\title{
Segmentation by Motivational Factors of Fantasy Football Consumers and Differences Among Segments
}
Authors' contribution:
A) conception and design of the study
B) acquisition of data
C) analysis and interpretation of data
D) manuscript preparation
E) obtaining funding

\author{
Demirhan Oğuzhan ${ }^{1 \text { A-C }}$, Eskiler Ersin ${ }^{1 \text { A-E }}$, Altunışık \\ Remzi $^{1 \text { C-E }}$ \\ ${ }^{1}$ Sakarya University, Turkey
}

ABSTRACT

Market segmentation and consumer motivation are among the most important concepts utilized in the prediction and explanation of consumer behavior. Although fantasy sports consumption has shown a remarkable growth in recent years, there has been limited research on the characteristics of participants of this activity, motivational factors influencing participation, and the effects of these factors on consumer behavior and preferences. For this purpose, we aimed to reveal the motives of fantasy football consumers, to comprise motivational market segments, and to show the potential differences between the segments in terms of experience. In the present study, we used non-hierarchical clustering (K-mean analysis) and hierarchical clustering (Ward cluster algorithm) analyses to determine the number of segments. In addition, we analyzed the potential differences between segments using ANOVA and chi-square analyses. As a result, we found that fantasy football consumers were classified into three different segments (loyal gamblers, hedonists, and casual players) with a motivational basis for the different behavioral responses. According to difference analysis, the consumers who are in different segments were found to be statistically different in terms of consumption behavior and experiential characteristics. The theoretical and practical effects of the study results were evaluated for academicians and practitioners.

\section{Introduction}

Participation in fantasy sports is a developing sector thanks to the widespread use of technology and the internet (Farquhar \& Meeds 2007) and has been expanding day by day. Studies on the rate of participation in fantasy sports support these conclusions (Dwyer \& Kim 2011; Shipman 2001; Larkin 2015; Comeau 2007). In a study that included both Turkey and other leading European countries, it was identified that participants played fantasy sports between 1.5 and 2.5 hours a week and Turkish participants ranked number two by spending 2.2 hours a week (Global Sports Media Consumption Report 2013). Likewise, it is known that nearly 75 million individuals are interested in fantasy sports in the United States and Canada (Dimisa 2016; https://fsta.org/research/industry-demographics/). Interest in participation in fantasy sports has created a similar interest among marketing academicians and practitioners focused on exploring the reasons for 
participating in fantasy sports and strategies to sustain and/or increase participation in fantasy sports. In particular, exploring participation motivation for fantasy sports and the consumption patterns of buyers (Dwyer, Shapiro, \& Drayer 2011; Ruihley 2010), as well as the creation of correct marketing reactions in line with consumers' needs and desires (Eskiler, Ozmen, \& Uzkurt 2011), are very important issues. The fact that a growing number of individuals are increasingly participating in online games such as fantasy sports results in motivational differences among participants (Tseng 2011). Although studies have detailed individuals' motivation for participation in fantasy sports (Farquhar \& Meeds 2007; Dwyer \& Kim 2011), it has been observed that these studies generally investigate motivational factors on individual levels instead of market segmentations (Dwyer et al. 2011). There are studies that examine sports consumers' demographic characteristics, such as sex, age, income, and educational status, and explore behavioral and attitudinal differences among the variables. However, there is a limited number of studies that investigate consumers' behaviors by primarily using market segmentation (Dwyer et al. 2011). Grouping consumers with similar wishes and demands in the same market into smaller segments will make organizations or service providers enhance products that are to be launched and improve their marketing efforts in terms of marketing quality, activities, and productivity (Greenberg \& McDonald 1989; Haley 1984).

In particular, the number of studies on the segmentation of fantasy sports/football market (Dwyer et al. 2011; Larkin 2015; Dwyer 2013) is quite limited, which emphasizes a crucial knowledge deficit in the literature. The purpose of the present study is to eliminate this knowledge deficit, explore fantasy football consumers' motivational factors, split these consumers into segmentations in terms of their motivational levels, and examine segmentation differences in terms of experiential factors. Therefore, it is predicted that the study results will provide useful information for corporations that work in the fantasy football sector so that they can develop and apply different strategies for different market segments. In addition, the findings can also be used by marketers to discover differences in the target market or to enter a new market.

\section{Literature Review}

\section{Market segmentation in sports}

Market segmentation is defined as "dividing a market into smaller segments of buyers with distinct needs, characteristics, or behaviors that might require separate marketing strategies or mixes" (Kotler \& Armstrong 2011, p. 190). This term, first used by Wendell Smith (1956), later resulted in a debate of numerous studies on marketing and has been utilized by organizational managements as one of the most important tools (Kotler \& Keller 2009). After organizations sort a whole market into different groups using the segmentation technique, they determine the segmentations for which they can develop effective strategies and construct a marketing combination for these determined segmentations. Thus, changes in the market can be better observed, effective and productive promotion strategies can be produced, and resources can be used in a more productive way to meet the needs of consumers who are sorted into subgroups (Mucuk 2001). In addition, it may be argued that organizations can present more productive goods and/or services or can achieve lower costs in the target market (Armstrong \& Kotler 2000).

It is suggested that the market segmentation strategy has widely been used in the sports sector (Pitts, Fielding, \& Miller 1994; Kim \& Korea 1998; Dwyer \& Drayer 2010; Funk 2002; Dixon, Backman, Backman, \& Norman 2012). For example, Pitts et al. (1994) divided the sports sector into three parts in line with Porter's (1985) recommendations (sports performance, sports production, and sports promotion). Similarly, Funk (2002) examined sports consumers under three groups through micro-segmentation (casual, moderate, and loyal consumers). On the other hand, Kim and Korea (1998) investigated members of sports centers under five different parts in terms of service quality attitudes, while Dixon et al. (2012) examined sports tourists under three different parts in terms of expenditure-based segmentations. In the study of Duman, Taskin, Gokce, and Zobar (2015), football spectators were split into two groups in terms of demographic characteristics, purchase intentions, trademark identity, frequency of licensed products, and participation in club events. They concluded that the groups differed depending on these variables (Duman et al. 2015). In addition to splitting consumers 
according to socio-demographic characteristics such as age, sex, and income status (Dwyer \& Kim 2011; Dwyer 2013), classifying consumers according to consumption habits (Ruihley 2010) and consumption motivation (Billings \& Ruihley 2013; Dhurup \& Dlodlo 2013) may make market segmentation more useful (Rohm, Milne, \& McDonald 2006; Green-Demers, Pelletier, Stewart, \& Gushue 1998). Previous studies emphasize that determining the motivations and needs of sports consumers in relation to the product is effective in creating basic strategies (Trail, Fink, \& Anderson 2003). Actually, the study of Tseng (2011) on online games and the study of Dwyer et al. (2011) on fantasy baseball consumers suggest that the segmentation of these consumer groups by motivational factors will help service producers and future markets as an effective and productive tool.

\section{Fantasy football participation and consumers' motivations}

Fantasy sport is defined as "games in which real players of many games such as car races, golf, basketball, football, baseball, ice hockey organized worldwide are selected using imaginary budgets and teams are constructed and players in these teams score points depending on their real performances (Dimisa 2016). The first study on fantasy sports participation was undertaken by the Indiana University Sports and Entertainment Academy in 2000 in order to identify the demographic characteristics of fantasy sports players and their motivation for participating in these games. In this study, it was reported that spending time with friends $(90 \%)$ was the primary motivation and entertainment was the secondary motivation (60\%) in participating in fantasy sports (Indiana University 2000). Actually, Simon (1959) states that motivation is the basis of consumer behavior studies because it plays a catalyst role in the consumer decision process (Simon 1959; cited by Dwyer et al. 2011). In other words, gaining an understanding of why a consumer demonstrates a certain behavior requires correctly finding and explaining motivational factors (Islamoglu \& Altunisik 2013). In this context; the study of Farquhar and Meeds (2007) exploring the motivation behind fantasy sports participation indicated five primary motivations: entertainment, escape, arousal, social interaction, and surveillance. On the other hand, the study of Dwyer and Kim (2011) argued that fantasy football participants were motivated by gambling, competition, entertainment/escape, and social interaction. The study concluded that gambling was not as effective of a motivational factor as the other factors.

In summary, the literature review points out the fact that there is a need for attaining additional information about the effect of market segmentation strategies on sports, the consumer motivation process, consumer behaviors, and especially fantasy football consumers. In this respect, it is important a) to investigate fantasy football consumers' possible reasons for participation using the fantasy football participation motivation scale, b) to determine the market segmentation on fantasy football motives, and c) to find possible differences in consumers' fantasy sports consumption based on different fantasy football segments.

\section{Methods}

In this study, a general survey model was used and the study population was composed of fantasy football consumers aged 18 and older and who actively joined the study during the data collection period. The link address of the questionnaire form created within the scope of the research was sent via e-mail to participants, who received links to the relevant game sites and social media accounts. Therefore, the data were collected from 509 active fantasy football participants selected using judgmental sampling and the online survey method. Table 1 includes the demographic characteristics of the participants.

The "Motivational Scale for Fantasy Football Participation (MSFFP)," designed by Dwyer and Kim (2011), and its validity and reliability tests, performed by Eskiler, Demirhan, and Soyer (2017), were used in the present study. The scale consists of 17 items and 4 sub-dimensions. These sub-dimensions are social interaction ( 4 items), gambling (5 items), competition ( 4 items), and entertainment/escape ( 4 items). The items in this scale use a 7-point Likert-type measure and scale options ranged from 1 (strongly disagree) to 7 (strongly agree). Cronbach alpha values of the sub-dimensions are $0.87,0.87,0.86$, and 0.79 , respectively (Dwyer \& Kim 2011). In the study carried out by Eskiler et al. (2017), the Cronbach alpha values of the sub-dimensions 
are $0.81,0.76,0.77$, and 0.72 , respectively, and the total Cronbach alpha value is 0.81 . EFA was performed in order to reduce the sub-dimensions of the MSFFP with $17 \mathrm{items,}$ and the findings of the analysis indicated four basic motivational factors. In addition, three items, unanimously accepted by researchers after a literature review, were added to the scale in order to discover the future tendencies of participants related to fantasy football games (Zeithaml, Berry, \& Parasuraman 1996). These three items target participants' intentions to continue in their current league, return to fantasy sport in the following season, and play different fantasy sport games. These items have a 7-point Likert format with the same coding. For analyses of the data, the following were used: descriptive analyses, hierarchical and non-hierarchical clustering to classify the participants, oneway analysis of variance, and chi-square tests to investigate the differences among clusters (Tabachnick \& Fidell 2012). In the current study, k-means were used in non-hierarchical clustering analysis to determine the number of clusters (segments), and the Ward clustering algorithm method was used in hierarchical clustering analysis. This method is employed to determine the number of clusters and to analyze group membership when the researcher does not know the number of clusters beforehand (Ketchen Jr. \& Shook 1996; Nakip 2006; Punj $\&$ Stewart 1983). This method is widely used in attitudinal studies to split the market into segments and find differences among the market segments (Kaufman \& Rousseeuw 2005).

Table 1. Socio-demographic characteristics of the study participants

\begin{tabular}{lcc}
\hline Gender & $\mathbf{N}$ & $\mathbf{\%}$ \\
\hline Female & 41 & 8.1 \\
\hline Male & 468 & 91.9 \\
\hline Age & $\overline{\mathbf{X}}$ & $\mathbf{S D}$ \\
\hline Range 18-42 & 24.30 & 4.824 \\
\hline Personal income & $\overline{\mathbf{X}}$ & $\mathbf{S D}$ \\
\hline Range 350TL-4750TL & 1135.40 & 879.664 \\
\hline Educational status & $\mathbf{N}$ & $\mathbf{\%}$ \\
\hline High school & 109 & 21.4 \\
\hline Undergraduate and graduate & 400 & 78.6 \\
\hline
\end{tabular}

Source: Own study.

When the demographic characteristics of the participants were examined, their average age was identified to be $\overline{\mathbf{X}}=24.30 \pm 4.824$ years, and the majority of them were male (91.9\%). In terms of income status, it was found that the participants' average monthly income was $\overline{\mathbf{X}}=1135.40 \pm 879.664$ Turkish Lira, and 78.6\% of them had university degrees or higher.

Table 2. Fantasy football experience

\begin{tabular}{lcc}
\hline How often do you visit the fantasy football website? & $\mathbf{N}$ & $\mathbf{\%}$ \\
\hline 1-2 times a week & 178 & 35 \\
\hline 3-4 times a week & 139 & 27.3 \\
\hline 5 times a week or more & 192 & 37.7 \\
\hline $\begin{array}{l}\text { How much time do you spend on each visit to the fantasy } \\
\text { football website? }\end{array}$ & $\mathbf{N}$ & $\mathbf{\%}$ \\
\hline$\leq 30$ minutes & 205 & 40.3 \\
\hline 31-60 minutes & 176 & 34.6 \\
\hline$\geq 61$ minutes & 128 & 25.1 \\
\hline How many different leagues do you play? & $\mathbf{N}$ & $\mathbf{\%}$ \\
\hline 1 league & 314 & 61.7 \\
\hline 2 leagues & 120 & 23.6 \\
\hline 3 or more leagues & 75 & 14.7 \\
\hline Sour: Ow
\end{tabular}

Source: Own study.

As shown in Table 2, 35\% of the participants visited fantasy football websites once or twice a week, while $27.3 \%$ and $37.7 \%$ of them visited 3-4 times and $\geq 5$ times a week, respectively. Of the total participants, $40.3 \%$ spent an average time of $\leq 30$ minutes visiting the websites. Most of the fantasy football participants $(61.7 \%)$ played in only one league. 


\section{Results}

As a result of EFA, it was shown that the MSFFP had 17 items and a 4-factor structure. The KaiserMeyer-Olkin (KMO) value was found to be 0.896 , and Bartlett's test of sphericity was significant $(\mathrm{p}<0.001)$. It was found that the Cronbach's alpha values of the MSFFP ranged from 0.802 to 0.895 , and the total Cronbach's alpha value was 0.877 , which was found to be acceptable (Altunisik, Coskun, Bayraktaroglu, \& Yildirim 2012; Buyukozturk 2016). In the MSFFP, the "Competition" sub-dimension had the highest average scores $(\overline{\mathbf{X}}=5.74 \pm 1.138)$, followed by the "Entertainment/Escape" sub-dimension $(\overline{\mathbf{X}}=5.72 \pm 1.039)$, "Social interaction" sub-dimension ( $\overline{\mathrm{X}}=5.35 \pm 1.454)$, and "Gambling" sub-dimension ( $\overline{\mathrm{X}}=3.55 \pm 1.809)$, respectively.

Table 3. Factor analysis of the motivations for playing fantasy football games

\begin{tabular}{|c|c|c|c|c|c|c|c|}
\hline Factors & Items & 1 & 2 & 3 & 4 & $\overline{\mathbf{X}}$ & SD \\
\hline \multirow{5}{*}{ Gambling } & Gam 3 & 0.896 & & & & \multirow{5}{*}{5.35} & \multirow{5}{*}{1.454} \\
\hline & Gam 2 & 0.879 & & & & & \\
\hline & Gam 4 & 0.824 & & & & & \\
\hline & Gam 5 & 0.802 & & & & & \\
\hline & Gam 1 & 0.750 & & & & & \\
\hline \multirow{4}{*}{$\begin{array}{l}\text { Social } \\
\text { Interaction }\end{array}$} & Soc 3 & & 0.874 & & & \multirow{4}{*}{3.55} & \multirow{4}{*}{1.809} \\
\hline & Soc 1 & & 0.861 & & & & \\
\hline & Soc 2 & & 0.839 & & & & \\
\hline & Soc 4 & & 0.725 & & & & \\
\hline \multirow{4}{*}{ Competition } & Com 2 & & & 0.815 & & \multirow{4}{*}{5.74} & \multirow{4}{*}{1.138} \\
\hline & Com 1 & & & 0.755 & & & \\
\hline & Com 4 & & & 0.721 & & & \\
\hline & Com 3 & & & 0.711 & 0.341 & & \\
\hline \multirow{4}{*}{$\begin{array}{l}\text { Entertainment/ } \\
\text { Escape }\end{array}$} & Ent 4 & & & & 0.829 & \multirow{4}{*}{5.74} & \multirow{4}{*}{1.138} \\
\hline & Ent 3 & & & 0.315 & 0.757 & & \\
\hline & Ent 2 & & & 0.408 & 0.609 & & \\
\hline & Ent 1 & & & & 0.478 & & \\
\hline \multicolumn{2}{|l|}{ Total } & 3.565 & 3.088 & 3.009 & 2.217 & & \\
\hline \multicolumn{2}{|l|}{ \% Variance } & 20.970 & 18.164 & 17.700 & 13.041 & & \\
\hline \multicolumn{2}{|c|}{ Cronbach's Alpha } & 0.895 & 0.885 & 0.831 & 0.802 & & \\
\hline \multicolumn{2}{|c|}{ Total Cronbach's Alpha } & & & 0.877 & & & \\
\hline \multicolumn{2}{|c|}{ Kaiser-Meyer-Olkin (KMO) } & & & 0.896 & & & \\
\hline \multicolumn{2}{|l|}{$\begin{array}{l}\text { Bartlett's Test of } \\
\text { Sphericity }\end{array}$} & \multicolumn{2}{|c|}{$\chi^{2}=4694.439$} & $\mathrm{df}=136$ & $\mathrm{p}<0.001$ & & \\
\hline
\end{tabular}

Source: Own study.

In light of these findings, the sample was split into segments according to the motivation dimensions of fantasy football participation. In order to classify the fantasy football participants, hierarchical clustering analysis was first performed and it was seen that consumers might be classified under three clusters with an agglomeration schedule and tree diagrams. Then, the number of clusters were determined by the "Range of solutions" (Nakip 2006). Since there were irregular deviations in the distribution of cluster members when the number of clusters increased and/or decreased, it was decided that the ideal number of clusters was three. Eventually, non-hierarchical clustering analysis was performed in order to determine the final cluster persons. The number of persons in clusters and the size of the clusters resulting from the analysis are shown in Table 4.

Table 4. Cluster sizes and distance between cluster centers

\begin{tabular}{|c|c|c|c|c|c|}
\hline \multirow[b]{2}{*}{ Clusters } & \multirow[b]{2}{*}{$\mathbf{n}$} & \multirow[b]{2}{*}{ Cluster Size (\%) } & \multicolumn{3}{|c|}{ Distances Between Final Cluster Centers } \\
\hline & & & Cluster 1 & Cluster 2 & Cluster 3 \\
\hline Cluster 1 & 154 & 30.3 & & 7.949 & 10.529 \\
\hline Cluster 2 & 256 & 50.3 & 7.949 & & 7.348 \\
\hline Cluster 3 & 99 & 19.4 & 10.529 & 7.348 & \\
\hline Total & 509 & 100 & & & \\
\hline
\end{tabular}

Source: Own study. 
When the findings were examined, there were 154 participants in the first cluster (30.3\%), 256 participants (50.3\%) in the second cluster, and 99 participants in the third cluster (19.4\%) (Table 4). When the distance among the clusters was investigated, it could be argued that the first cluster was distant from the third cluster, while the second cluster and third cluster were relatively close to each other. According to the result of one-way variance analysis, the variables were significant at 0.01 .

Figure 1. Three clusters of fantasy football participants by four motivational factors

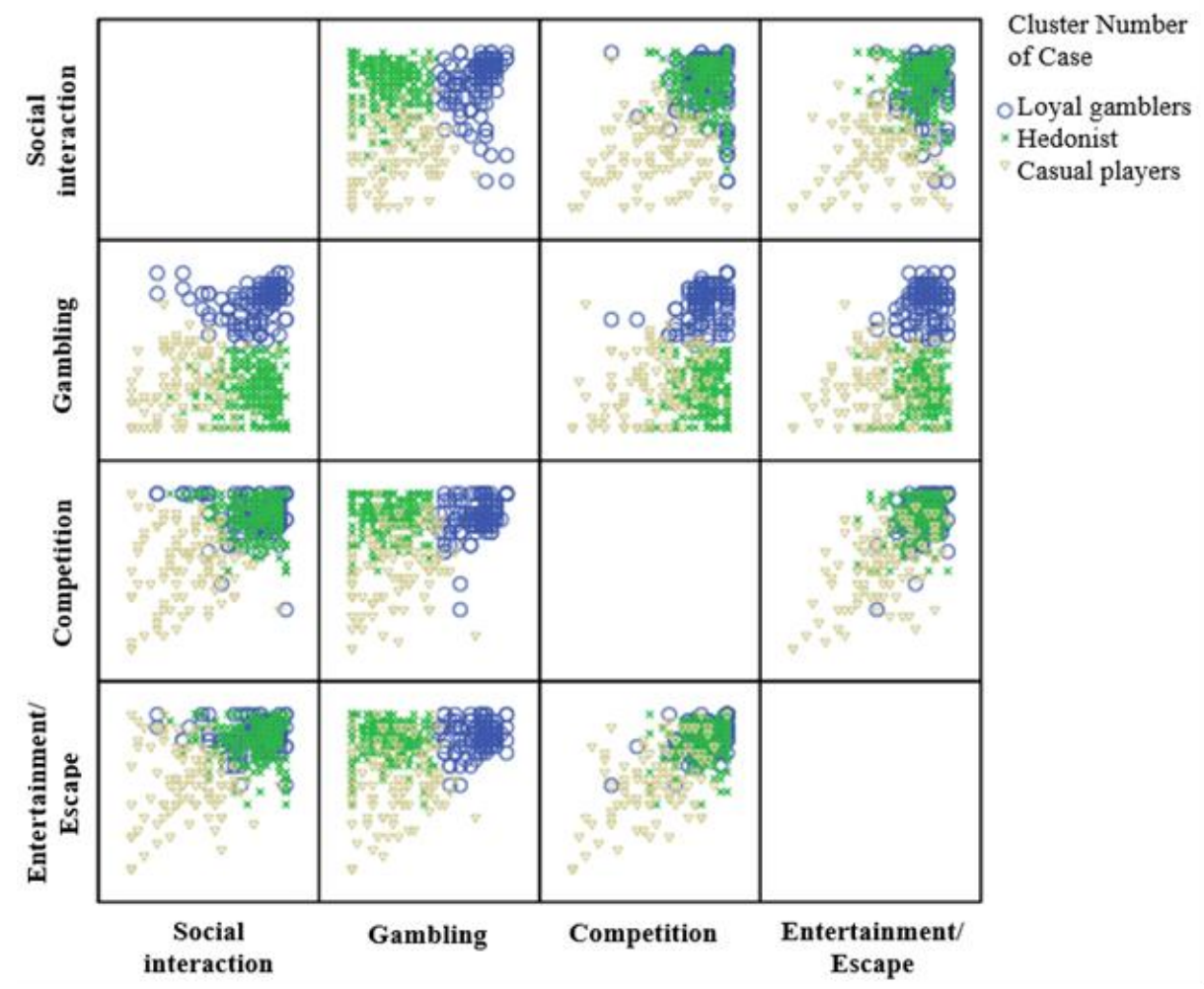

Source: Own study.

As a result of the clustering analysis, three clusters (segments) for participant motivation were determined for the fantasy football market (Fig. 1). Thus, each cluster was named as follows:

$>1^{\text {st }}$ market segment named "loyal gamblers": This segment was composed of those consumers who had the highest average motivation scores in each sub-dimension in comparison to other segments and general average scores.

$>2^{\text {nd }}$ market segment named "hedonists": It was found that consumers in this segment had a rather lower average gambling motivation score than those consumers in the first segment, but had higher average motivation scores than the general average scores in other sub-dimensions.

$>3^{\text {rd }}$ market segment named "casual players": These consumers had lower average motivation scores than the general average scores in each sub-dimension.

Table 5. Final cluster centers

\begin{tabular}{lcccc}
\hline & $\begin{array}{c}\text { Cluster 1 } \\
\text { Loyal gamblers }\end{array}$ & $\begin{array}{c}\text { Cluster 2 } \\
\text { Hedonists }\end{array}$ & $\begin{array}{c}\text { Cluster 3 } \\
\text { Casual players }\end{array}$ & Mean \\
\hline Social interaction & 5.963 & 5.827 & 3.172 & 5.352 \\
\hline Gambling & 5.944 & 2.419 & 2.729 & 3.546 \\
\hline Competition & 6.115 & 6.103 & 4.227 & 5.742 \\
\hline Entertainment/Escape & 6.161 & 5.960 & 4.419 & 5.721 \\
\hline Cluster Size (\%) & 30.3 & 50.3 & 19.4 & \\
\hline
\end{tabular}

Source: Own Study.

The distributions of the average scores of consumers in different market segments in the MSFFP subdimensions are presented in Table 5 and Figure 2 according to the findings. 
Figure 2. Fantasy football consumer cluster distribution by motivation

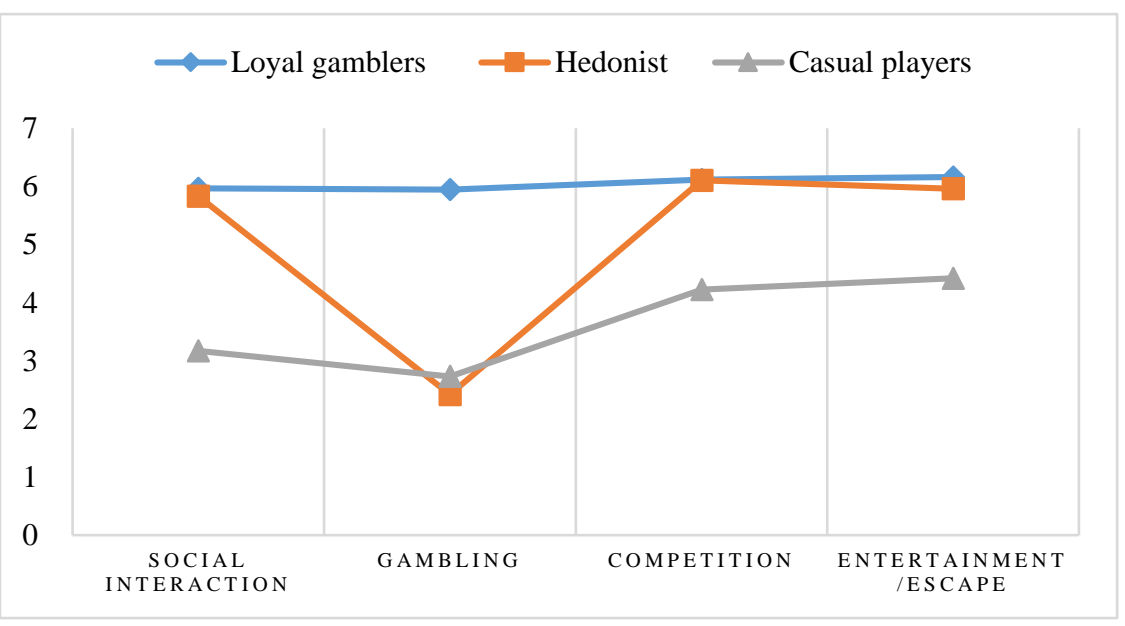

Source: Own study.

Table 6. Chi-square analysis results in terms of the fantasy football gaming experience

\begin{tabular}{|c|c|c|c|c|c|c|}
\hline Frequency of use (Week) & $\begin{array}{c}\text { Cluster 1 } \\
\text { Loyal gamblers }\end{array}$ & $\begin{array}{c}\text { Cluster } 2 \\
\text { Hedonists }\end{array}$ & $\begin{array}{c}\text { Cluster } 3 \\
\text { Casual players }\end{array}$ & Value & Sd. & $\left(\chi^{2}\right) \mathbf{p}$ \\
\hline $1-2$ & $25.3 \%$ & $35.9 \%$ & $47.5 \%$ & \multirow{3}{*}{14.869} & \multirow{3}{*}{4} & \multirow{3}{*}{0.005} \\
\hline $3-4$ & $30.5 \%$ & $28.9 \%$ & $18.2 \%$ & & & \\
\hline$\geq 5$ & $44.2 \%$ & $35.2 \%$ & $34.3 \%$ & & & \\
\hline \multicolumn{7}{|c|}{ Duration of use per visit (hours) } \\
\hline$\leq 30$ minutes & $27.9 \%$ & $40.2 \%$ & $59.6 \%$ & \multirow{3}{*}{28.963} & \multirow{3}{*}{4} & \multirow{3}{*}{0.000} \\
\hline $31-60$ minutes & $38.3 \%$ & $37.9 \%$ & $20.2 \%$ & & & \\
\hline$\geq 61$ minutes & $33.8 \%$ & $21.9 \%$ & $20.2 \%$ & & & \\
\hline \multicolumn{7}{|l|}{ Number of Active Leagues } \\
\hline 1 & $74.0 \%$ & $57.0 \%$ & $57.0 \%$ & \multirow{3}{*}{15.453} & \multirow{3}{*}{4} & \multirow{3}{*}{0.004} \\
\hline 2 & $16.2 \%$ & $27.3 \%$ & $27.3 \%$ & & & \\
\hline$\geq 3$ & $9.7 \%$ & $15.6 \%$ & $15.6 \%$ & & & \\
\hline
\end{tabular}

Source: Own study.

It was noted that the determined consumer segments differed depending on the fantasy football game experience. It was seen that in terms of the frequency of visits in one week, the majority of the loyal gamblers connected to the fantasy football game $\geq 5$ times (44.2\%), while casual players (47.5\%) and hedonists (35.9\%) connected to these sites once or twice a week. In terms of the average amount of time spent during each visit, loyal gamblers $(72.1 \%)$ and more than half of the hedonists $(50.8 \%)$ spent $\geq 31$ minutes, while casual players $(59.6 \%)$ spent $<30$ minutes. It is possible to argue that the consumers in each segment generally preferred to play in one league rather than multiple leagues.

Table 7. Differences between clusters in terms of future intentions

\begin{tabular}{|c|c|c|c|c|c|c|c|}
\hline & & Sum of Squares & df & Mean Square & $\mathbf{F}$ & $\mathbf{p}$ & Mean Difference \\
\hline \multirow{3}{*}{$\begin{array}{l}\text { Intention to } \\
\text { continue } \\
\text { playing fantasy } \\
\text { football this } \\
\text { year }\end{array}$} & $\begin{array}{l}\text { Between } \\
\text { Groups }\end{array}$ & 181.73 & 2 & 90.86 & 49.865 & 0 & $\mathrm{C} 1>\mathrm{C} 2>\mathrm{C} 3$ \\
\hline & $\begin{array}{l}\text { Within } \\
\text { Groups }\end{array}$ & 922.04 & 506 & 1.82 & & & \\
\hline & Total & 1103.76 & 508 & & & & \\
\hline \multirow{3}{*}{$\begin{array}{l}\text { Intention to } \\
\text { continue } \\
\text { playing fantasy } \\
\text { football next } \\
\text { year }\end{array}$} & $\begin{array}{l}\text { Between } \\
\text { Groups }\end{array}$ & 195.63 & 2 & 97.81 & \multirow{3}{*}{48.649} & \multirow{3}{*}{0} & \multirow{3}{*}{$\mathrm{C} 1, \mathrm{C} 2>\mathrm{C} 3$} \\
\hline & $\begin{array}{l}\text { Within } \\
\text { Groups }\end{array}$ & 1017.36 & 506 & 2.01 & & & \\
\hline & Total & 1212.99 & 508 & & & & \\
\hline
\end{tabular}




\begin{tabular}{|c|c|c|c|c|c|c|c|}
\hline \multirow{3}{*}{$\begin{array}{l}\text { Intention to } \\
\text { participate in } \\
\text { different } \\
\text { fantasy football } \\
\text { games in the } \\
\text { future }\end{array}$} & $\begin{array}{l}\text { Between } \\
\text { Groups }\end{array}$ & 177.71 & 2 & 88.85 & \multirow{3}{*}{33.824} & \multirow{3}{*}{0} & \multirow{3}{*}{$\mathrm{C} 1, \mathrm{C} 2>\mathrm{C} 3$} \\
\hline & $\begin{array}{l}\text { Within } \\
\text { Groups }\end{array}$ & 1329.26 & 506 & 2.63 & & & \\
\hline & Total & 1506.97 & 508 & & & & \\
\hline$p<0.01$ & & & & & & & $\begin{array}{l}\text { oyal gamblers; C2: } \\
\text { C3: Casual players }\end{array}$ \\
\hline
\end{tabular}

Source: Own study.

As seen in Table 7, it was identified that there were significant differences among the segments in terms of future tendencies $(\mathrm{p}<0.01)$. According to the results of the Scheffe test, all the segments were statistically different from each other in terms of the participants' intentions to continue playing in the league in this year. Loyal gamblers demonstrated a more positive tendency than other segments in terms of intentions to continue to participate in fantasy sports in the next year and intentions to play different fantasy football games, and both loyal gamblers and hedonists differed in a statistically significant manner from casual players $(\mathrm{p}<0.01)$.

\section{Discussion}

The development and popularity of fantasy sports games have been increasing fast, and therefore participation rates are increasing, too (Farquhar \& Meeds 2007). However, it may be argued that there is a limited knowledge concerning the exploration of different attitudes and behaviors of fantasy sports players (Dwyer et al. 2011). Particularly, there is a need to explain the motivations and behaviors of fantasy football players nationwide in relation to cultural features. Additionally, participants of fantasy sports are internationally considered to be a very large and profitable sports market; therefore, classifying them according to psycho-graphic features will make it possible for sports marketing personnel, web service providers, and other business managers to develop more effective and useful communication. When the study findings were assessed in relation to other study findings, clustering analysis showed fantasy football participants classified into three different market segments, and the chi-square test and one-way variance analysis demonstrated that the consumers in these segments may differ in terms of consumption experiences and future consumption tendencies.

Although the first segment, named "loyal gamblers" ( $n=154,30.3 \%)$, had the highest motivation score in each sub-dimension, the most important motivational factor that distinguished this segment from the others was gambling motivation. Considering participation frequencies, average time spent playing fantasy sports games (Table 6), and possible consumption tendencies (Table 7), it may be argued that they are relatively the most loyal consumer group. On the other hand, considering the number of the leagues in which the participants played, the majority of them (74\%) played in just one league. It may be suggested that the consumers whose average gambling motivation score was high showed a tendency to specialize in one league, and the potential financial benefits of participating in fantasy football were their most significant motivation. Although this result concurred with the motivations of the consumer group called "Opportunist" in the study of Dwyer et al. (2011), consumers in this segment showed a moderate attitude in terms of consumption tendency. On the other hand, members of the loyal gamblers segment in this study were similar to the consumer segment called "Skilled Players" in the study of Farquhar and Meeds (2007) in terms of their consumption tendencies.

The second cluster was named "hedonists" ( $\mathrm{n}=256,50.3 \%)$. Although consumers in this segment were quite similar to those in the first segment (loyal gamblers) in terms of competition, entertainment/escape, and social interaction, there was a significant difference in gambling motivation levels. On the other hand, these consumers were different from others in terms of participation frequencies and average time spent playing fantasy sports games, and they had neither the highest nor the lowest average score in terms of future consumption tendencies. It may be stated that these consumers were mostly interested in entertainment/escape and competition, and that they formed the largest consumer segment in terms of the number of cluster persons. 
The third segment, "casual players" ( $\mathrm{n}=99)$, represented a segment that had lower motivation scores in each sub-dimension than the average scores belonging to the whole sample. The statistically significant differences between the segments generally resulted from the lower motivation and behavioral intentions of this third group, and therefore it may be argued that these consumers were less interested in fantasy sports football. Special marketing efforts are required to keep the consumers in this third segment and encourage these consumers to improve their long-term relationships with service providers.

In the present study, the motivational factors that affect online consumers' participation in fantasy football games were investigated. Four factors of participation in online fantasy football games were determined. According to the degree of effect, these factors were competition, entertainment/escape, social interaction, and gambling. Based on these four factors, fantasy football consumers were classified as loyal gamblers, hedonists, and casual players. Among these three consumer segments, considerable differences were found in terms of behavioral characteristics such as time spent playing games, frequency of playing games, and intention to play games in the future. Therefore, fantasy football service providers should develop different marketing strategies for different consumer segments. Also, these findings can be used by marketers to explore differences in the current market and/or to enter new markets. In the future, studies that discover the different factors that motivate fantasy football consumers will contribute to the results of the current study. In addition, different studies that focus on other fantasy sports games and/or online players of other games can contribute to the literature for both fantasy sports and the digital game sector.

\section{REFERENCES}

Altunisik, R., Coskun, R., Bayraktaroglu, S., \& Yildirim, E. (2012). Sosyal bilimlerde arastirma yontemleri [Research Methods in Social Sciences]. Sakarya: Sakarya Publishing.

Armstrong, G. \& Kotler P. (2000) Marketing: An Introduction. Upper Saddle River, NJ: Prentice Hall, Inc.

Billings, A.C. \& Ruihley, B.J. (2013). Why we watch, why we play: The relationship between fantasy sport and fanship motivations. Mass Commun. Soc., 16(1), 5-25. DOI: 10.1080/15205436.2011.635260.

Buyukozturk, S. (2016). Sosyal bilimler icin veri analizi el kitabi [Data Analysis Handbook for Social Sciences]. Ankara: Pegema Publishing.

Comeau, T.O. (2007). Fantasy football participation and media usage. Unpublished doctoral dissertation, University of Missouri, Columbia, MO.

Dhurup, M. \& Dlodlo, N. (2013). To play or not to play! Online fantasy football consumption motives and the relationship with attitude and future behavioural intentions. Mediterranean Journal of Social Sciences, 4(14), 201-211. DOI: $10.5901 / \mathrm{mjss} .2013 . v 4 \mathrm{n} 14 \mathrm{p} 201$.

Dimisa, A. (2016, Nov 4). The popularity of fantasy sports continues to grow. Retrieved November 30, 2017, from http://www.fordhamobserver.com/the-popularity-of-fantasy-sports-continues-to-grow/

Dixon, A.W., Backman, S., Backman, K., \& Norman, W. (2012). Expenditure-based segmentation of sport tourists. Journal of Sport \& Tourism, 17(1), 5-21. DOI: 10.1080/14775085.2011.635017.

Duman, C., Taskin, E., Gokce, Z., \& Zobar, L. (2015). Clustering consumers through their football involvement levels and differences between clusters. Journal of ONERI, 11(43), 71-88. DOI: 10.14783/od.v11i43.5000070103.

Dwyer, B. \& Drayer, J. (2010). Fantasy sport consumer segmentation: An investigation into the differing consumption modes of fantasy football participants. Sport Marketing Quarterly, 22(1), 33-47.

Dwyer, B. \& Kim, Y. (2011). For love or money: Developing and validating a motivational scale for fantasy football participation. J. Sport Manage, 25(1), 70-83. DOI: 10.1123/jsm.25.1.70.

Dwyer, B. (2013). The impact of game outcomes on fantasy football participation and National Football League media consumption. Sport Marketing Quarterly, 22(1), 33-47.

Dwyer, B., Shapiro, S.L., \& Drayer, J. (2011). Segmenting motivation: An analysis of fantasy baseball motives and mediated sport consumption. Sport Marketing Quarterly, 20, 129-137.

Eskiler, E., Demirhan, O., \& Soyer, F. (2017). Turkish validity and reliability study of "motivational scale for fantasy football participation." Journal of Physical Education and Sports Sci, 11(2), 159-169.

Eskiler, E., Ozmen, M., \& Uzkurt, C. (2011). The relationship of knowledge management market orientation and marketing innovation: A research on furniture industry. Eskisehir Osmangazi University Journal of Economics and Administrative Sciences, 6(1), 31-69. 
Farquhar, L.K. \& Meeds, R. (2007). Types of fantasy sports users and their motivations. J. Comput.-Mediat. Comm., 12(4), 1208-1228. DOI: 10.1111/j.1083-6101.2007.00370.x.

Funk, D.C. (2002). Consumer-based marketing: The use of micro-segmentation strategies for understanding sport consumption. Int. J Sport Mark. Spo., 4(3), 39-64. DOI: 10.1108/IJSMS-04-03-2002-B004.

Greenberg, M. \& McDonald, S.S. (1989). Successful needs/benefits segmentation: A user's guide. J. Consum. Mark., 6(3), 29-36. DOI: 10.1108/EUM0000000002552.

Green-Demers, I., Pelletier, L.G., Stewart, D.G., \& Gushue, N.R. (1998). Coping with the less interesting aspects of training: Toward a model of interest and motivation enhancement in individual sports. Basic Appl. Soc. Psych., 20(4), 251-261. DOI: 10.1207/s15324834basp2004_2.

Haley, R.I. (1984). Benefit segments: Backwards and forwards. J. Advertising Res., 24(1), 19-25.

Indiana University, Sports and Entertainment Academy, Kelley School of Business. (2000). It's football, friends, and fun, but few women interested in sports fantasy leagues, study finds. Retrieved November 30, 2017, from http://www.iuinfo. indiana.edu/ocm/ releases/fantasy.htm

Islamoglu, A.H. \& Altunisik, R. (2013). Tuketici davranislari [Consumer Behavior]. Istanbul: Beta Publications.

Ketchen Jr., D.J. \& Shook, C.L. (1996). The application of cluster analysis in strategic management research: An analysis and critique. Strategic Management Journal, 441-458.

Kim, C. \& Korea, S.Y.K. (1998). Segmentation of sport center members in Seoul based on attitudes toward service quality. J. Sport Manage., 12(4), 273-287. DOI: 10.1123/jsm.12.4.273.

Kotler, P. \& Armstrong, G. (2011). Principles of Marketing. Upper Saddle River, NJ: Prentice Hall, Inc.

Kotler, P. \& Keller, K.L. (2009). Marketing Management. Upper Saddle River, NJ: Prentice Hall, Inc.

Larkin, B. (2015). An examination of fantasy sport participation motives and substitution versus attendance intention. Sport Marketing Quarterly, 24(2), 120-133.

Mucuk, İ. (2001). Pazarlama ilkeleri [Marketing Principles]. Istanbul: Turkmen Publishing.

Nakip, M. (2006). Pazarlama arastirmalari teknikler ve uygulamalar [Marketing Research Techniques and Applications]. Ankara: Seckin Publications.

Pitts, B.G., Fielding, L.W., \& Miller, L.K. (1994). Industry segmentation theory and the sport industry: Developing a sport industry segment model. Sport Marketing Quarterly, 3(1), 15-24.

Punj, G. \& Stewart, D.W. (1983). Cluster analysis in marketing research: Review and suggestions for application. $J$. Marketing Res., 134-148. DOI: 10.2307/3151680.

Rohm, A.J., Milne, G.R., \& McDonald, M.A. (2006). A mixed-method approach for developing market segmentation typologies in the sports industry. Sport Marketing Quarterly, 15(1), 29-39.

Ruihley, B.J. (2010). The fantasy sport experience: Motivations, satisfaction, and future intentions. Unpublished doctoral dissertation, Tennessee University, Knoxville, TN.

Shipman, F.M. (2001). Blending the real and virtual: Activity and spectatorship in fantasy sports. Digital Arts and Culture 2001 Conference, 26-28 April 2001 (pp. 1-9). Providence, RI: Brown University.

http://www.csdl.tamu.edu/ shipman/papers/dac01.pdf.

Sport Business Group. (2013). The global sports media consumption report 2013. Retrieved November 30, 2017, from https://www.sportbusiness.com/global-sports-media-consumption-report

Tabachnick, B.G. \& Fidell, L.S. (2012). Using Multivariate Statistics. Boston, MA: Pearson.

Trail, G.T., Fink, J.S., \& Anderson, D.F. (2003). Sport spectator consumption behavior. Sport Marketing Quarterly, 72(1), 8-17.

Tseng, F.C. (2011). Segmenting online gamers by motivation. Expert Syst. Appl., 38(6), 7693-7697. DOI: 10.1016/j.eswa.2010.12.142.

Zeithaml, V.A., Berry, L.L., \& Parasuraman, A. (1996). The behavioral consequences of service quality. J. Marketing, 60(2), 31-46. DOI: $10.2307 / 1251929$.

AUTHOR'S ADDRESS: $\quad$ Ersin Eskiler

Sakarya University

Faculty of Sports Science

Esentepe Campus 54187

Sakarya/Turkey

E-mail: eeskiler@sakarya.edu.tr

Received: 26 January 2018; Accepted 16 March 2018 